ECONOMIC THEMES (2021) 59(3): 341-356

DOI 10.2478/ethemes-2021-0019

\title{
POTENTIALS OF MOUNTAIN TOURISM DEVELOPMENT OF SOUTHWESTERN SERBIA
}

\author{
Ljiljana Lešević \\ Tourism organization of Novi Pazar, Serbia \\ $\bowtie$ ljiljana1989@gmail.com
}

Dejan Ž. Đorđević

University of Nis, Faculty of Economics, Republic of Serbia

$\bowtie$ ekngeo@gmail.com

Vukašin Šušić

University of Nis, Faculty of Economics, Republic of Serbia

$\bowtie$ vukasin.susic@eknfak.ni.ac.rs

UDC

338-48-44

(23.0)

Review

paper

Received:

13.02.2021

Accepted:

02.07.2021
Abstract: Mountain areas with their environment and facilities, appear as important parts of tourist regions with a potential for the development of complementary activities and a year-long tourism. Possibilities for the development of mountain tourism depend on the size of the mountain area, the nature protection regime, the equipment with infrastructure, the creation of conditions for vacation and recreation and the involvement of the local population in the process of development and protection. The area of southwestern Serbia has a quality and diverse potentials for the development of mountain tourism, of which only a part has been activated. The paper analyzes the potentials and various possibilities for the development of mountain tourism with a special emphasis on the mountains of southwestern Serbia.

Keywords: mountain tourism, mountain centers, southwestern Serbia, Zlatibor, tourism potential

JEL classification:

\section{Introduction}

The mountains in the Republic of Serbia differ in morphological characteristics, dimensions, vegetation, way of origin, etc. Therefore, they are not equally suitable 
for certain forms of human activities, so the prospects for the development of mountain tourism are different for each part of our country.

Mountains have always attracted the attention of nature lovers, tourists and mountaineers. In Serbia, mountain areas are generally well-preserved, so there is a basis for their tourist valorization and arrangement. However, the development of tourism in mountainous areas is influenced by internal and external factors. The key ones are: the quality of the tourist offer in the winter and summer season, the overall image of the destination, the sense of security, as well as the overall impression of the quality of destination management. The current practice of tourism development in the mountains of the Republic of Serbia has shown that some of the above elements are not sufficiently met. Tourist infrastructure and superstructure in the mountains of ssouthwestern Serbia are developing according to generally accepted rules and standards, with certain deviations. If we take into account that for the development of mountain tourism, the greatest opportunities are provided by high mountain areas, over $1200 \mathrm{~m}$ above sea level, it can easily be concluded that the area of southwestern Serbia has a huge potential for the mountain tourism development, because all the mountains in this area meet this criterion. According to the realized tourist traffic, the level of tourism development and the construction of tourist infrastructure and superstructure in the mountain tourism of southwestern Serbia, Zlatibor stands out, which, besides Kopaonik, is the most developed mountain center in the Republic of Serbia.

\section{Basic characteristics of mountain tourism}

According to the spatial representation and mass, mountain tourism is the most important type of continental tourism. Also, after the coastal, mountain tourism is the most important type of recreational tourism. The recreational values on which mountain tourism is based are altitude, relief breakdown, climatic, hydrographic and biogeographical characteristics. Of all the above, the most important are the climatic characteristics, because the formation of the summer and winter seasons depends on them, and thus the traffic of tourists. The importance of climate during the winter half of the year is based on the thickness and the length of snow, while in the summer the basic climatic parameters that affect the tourist season are air temperature, the length of sunshine, precipitation, cloudiness, etc.

In addition to altitude, which directly affects the general commitment of the mountain to certain forms of tourism, other morphometric parameters of the mountains also play a significant role. These properties significantly concretize the use of certain mountain localities and micro-localities and complete the tourist offer of the mountains (Romelić, 2008).

In addition to morphometric properties, the characteristics of snow cover and other climatic and hydrographic conditions, the construction of tourist 
infrastructure also plays an important role, as well as the proximity of strong emitting centers and roads of national importance. Accordingly, the proximity of an airport has a positive effect on the level of attendance, primarily of foreign visitors. The proximity of large emitting centers, such as metropolitan cities in the area, allows winter centers to fill the capacity throughout the season in the form of board or day guests.

It should be emphasized that the importance of mountain tourism is not only natural, but it also has anthropogenic tourist values. Mountain areas are characterized by better preserved local culture, folklore, the hospitality of the local population, gastronomy and the like. Of course, mountain tourism requires a whole range of prerequisites to thrive. The attractiveness of mountain destinations and the successful development of tourism also depend on security, local entrepreneurship and available financial resources. For the optimal use of available tourist potential, a significant capital is needed for the construction of infrastructure and receptive facilities, high costs of investment in infrastructure and superstructural facilities hinder the profitability of tourism, and, therefore, the development of mountain tourism should focus on the most attractive mountains. Southwestern Serbia has a significant potential in mountain tourism, but due to all the above, it is illusory to expect that it is possible to build sustainable tourist centers on all mountains.

The beginnings of mountain tourism in the world were based mainly on the summer season. The massification of winter sports tourism, i.e. the popularization of skiing in the middle of the last century, led to a higher capacity utilization in the winter months, i,e. to the stagnation of summer mountain tourism. It is not difficult to conclude that for the revitalization of summer tourism in the mountains, it is necessary to create conditions for the implementation of innovative programs that will be aimed at new target groups and new products. Traditional visitors to mountain destinations are families, older categories of the population, and more recently, young, sports and adventure-oriented visitors. Therefore, it is necessary to create a tourist product of mountain destinations according to the needs of the new categories of tourist clientele, that is, it is necessary to adapt the tourist product in the mountains to all segments of tourist demand (Spasojević, Šušić, 2016).

Tourists who love sports often belong to the well-paid visitors, and are also inclined to travel to distant destinations. In addition to the desire for a healthy life, which is usually cited as the reason for the spread of sports tourism, there is also the rapid development and strong marketing of companies that produce sports equipment. The global popularization of winter / summer extreme sports has been made possible by the development of roads, and especially by the reduction of air traffic and the emergence of low cost companies. Most of the participants in this type of tourism are younger residents of urban areas, eager for action and new experiences, looking for excitement and adventure. Following these trends in the 
development of tourism, new ways of profitable use of mountain potentials are constantly being developed (Mountains of the world, 1999).

It should be emphasized that another driver of the ever faster development of mountain tourism in the world is that mountain tourism corresponds to protected areas, because in the development of mountain tourism, the untouched nature has a high value. On the other hand, the abundance of protected areas in the mountain areas, which undoubtedly encourage the development of tourism, are not a guarantee of the development of sustainable tourism, the more mass in mountain tourism can lead to serious degradation of the natural environment (Debarbieux, 2014).

New strategies for the development and improvement of summer tourism in the mountains require the creation of new products, with the aim of completing the social life of different generations of tourists (outdoor cinemas, cultural events, gambling houses, nightlife, etc.). Monitoring new trends could overcome structural differences, such as seasonality and adverse weather conditions. Overcoming the problem of seasonality and bad weather in mountain tourism is easier to solve at the destination level than at the level of the wider area. Also, wellness products encourage mountain tourism, equally throughout the year, because this is one of the most important "indoor" activities during the adverse weather conditions on the mountain (Spasojevic, Susic, 2016).

\section{Position and morphological characteristics of the mountains of southwestern Serbia}

Southwestern Serbia is part of Dinaric Serbia, bordered by the state borders with Bosnia and Herzegovina, in the west, and Montenegro in the southwest and south, as well as the national administrative borders with AP Kosovo and Metohija and the municipalities of Raska, Ivanjica, Arilje and Uzice. The position of southwestern Serbia should be treated as a significant factor in the development of tourism. The basic significance of the geographical position of southwestern Serbia derives from its function of connecting the attractive and receptive factors of the tourist offer with important tourist centers that influence tourist flows in the country and abroad.

Morphologically, the territory of southwestern Serbia belongs to the Stari VlahRaska highland, a vast highland of Dinaric areas and wreaths, between the source of Raska and the Lim valley, intersected by the valleys of Uvac, Golijska Moravica and other smaller rivers. Southwestern Serbia is divided by gorges and canyon valleys on smaller plateaus from which the mountain ranges rise. It consists of southwestern Serbia smaller mountains, high and medium height, their plateaus (Pešter) and areas (Zlatiborska), which are dissected by gorges and canyon valleys, between which the valleys are lowered. Their petrological structure is diverse, the 
Peleozoic shales up to the youngest lake and Quaternary river sediments are represented, as well as metamorphic and sedimentary, as well as igneous, more extrusive than intrusive rocks (Marković, Pavlović, 1995). Among the mountains of southwestern Serbia, the following stand out: Zlatibor (1496m), Golija (1833m), Zlatar (1625m), Pobijenik (1423m), Giljeva (1617m), Jadovnik (1734m), Javor (1519m), Velika Ninaja (1352m), Jarut (1428m) and Rogozna (1479m).

The mountains of southwestern Serbia are presented as medium and high mountains of the Dinaric zone. All the mountains are characterized by great fragmentation and various relief forms. Mountains and plateaus, with their beauty, provide a visual and aesthetic experience of the landscape. The tourist potential of these mountain destinations is great and represents one of the most promising types of tourism in this part of the Republic of Serbia.

Zlatibor is the most famous and most visited mountain in southwestern Serbia. It is a peridotite lacolite imprinted in Paleozoic rocks, which stretches for about $300 \mathrm{~km}^{2}$. The high fluvial Zlatibor surface also cuts the limestone mountains. Zlatibor is one of the largest serpentine masses in Serbia. Its borders are represented by deep gorges and canyons, except for the western side. It stretches between Rzava and Kremanska kotlina in the west, the valley of Cetinje in the north, Veliki Rzav in the east, Zlatar lake and the valley of Uvac in the south. In the Dinaric direction, Zlatibor is about $55 \mathrm{~km}$ long, and in the northeast-southwest direction about $25 \mathrm{~km}$. The average altitude is $1,000 \mathrm{~m}$, and the highest peaks are Tornik (1,496 m), Čigota (1,422 m), Brijač (1,480 m) and Viogor (1,281 m). The mountain is well-visited and well-connected by traffic (railway, Zlatibor tunnel, asphalt road to the sea). Zlatibor is a mountain of exceptional beauty, with slightly undulating plateaus and high and steep slopes (Ršumović et al., 1991). The favorite recreational activity of the visitors to Zlatibor is a walk along numerous paths through the mountain, and due to the gentle slopes of the terrain, Zlatibor is a suitable destination for cycling - this mountain has the best maintained trails, both for hiking and biking.

After Zlatibor, Zlatar is one of the most famous mountains in southwestern Serbia with the highest peak Velika Krševa $(1,625 \mathrm{~m})$. This mountain has a very favorable geographical position because it is located between Uvac, Bistrica, Lim and Milesevka. According to its morphology, climate and vegetation cover, i.e. the authentic nature, Mount Zlatar is one of the important tourist regions, in which health-spa, hunting, sports-recreational, excursion, congress, excursion tourism and rural tourism can be developed. The diverse relief of Zlatar results in different slopes of the terrain, but it also has the status of an air spa, with numerous landscaped trails, but also great potential for the development of such tourist attractions.

Golija (Jankov kamen, 1,833 m) is the highest mountain in the southwestern part of Serbia with an area of 75,138 ha, and covers five municipalities. The arched 
mountain stretches for $32 \mathrm{~km}$. It is built of shale, dacite and andesite. Golia also has glacial traces. At the suggestion of the Institute for Nature Protection, Golija was declared by the MAB / UNESCO as a Biosphere Reserve "Golija - Studenica" on the area of 75,183 ha, and on the area of 53,804 ha as a nature park (Nikolić, Jovićić, 2004).

The exposure of the terrain on Mount Golija is predominantly northern, but there are also other exposures depending on the direction of the hair and the stream. This exposure and high slope of the terrain greatly affects the retention of the snow cover and a very good basis for the construction of ski slopes, infrastructure and the development of mountain tourism. On Zlatibor and Zlatar, the exposition is southern, which conditions a large number of sunny days, but also the presence of a climate of medium altitudes or subalpine, so these mountains have the status of an air spa. The average slope of the Golija mountain terrain is $60-70 \%$, which is a very good condition for the development of adventure tourism, cycling and hiking tours (Dinić, 1976).

The tourist values of the geomorphological features of the Golija mountain are reflected in the vast glades above $1200 \mathrm{~m}$ above sea level. and the peaks over $1400 \mathrm{~m}$ n.v. Tourism on Golija is developing at a high speed, and in the last decade, several smaller ski slopes and accompanying ski facilities have been built so far. During the winter, guests from Serbia and abroad visit the mountain (Nikolić, 2014).

Rogozna is a mountain located on the territory of the City of Novi Pazar, 10-12 $\mathrm{km}$ southeast of the city. It stretches in the southwest-northeast direction for about $20 \mathrm{~km}$. It is located in a triangle consisting of the river Raska and the upper and middle course of Ibar. The valleys of the tributaries of these rivers are divided into long slopes of very steep sides. The highest elevation is Crni vrh $(1,504 \mathrm{~m})$. Rogozna consists mostly of volcanic rocks of andesite, dacite, rhyolite and their tuffs, and in the northeastern part of crystalline shales of Upper Carboniferous age and rocks of diabase-hornblende formation. It is overgrown with dense forests. The Jeleč-grad paleovolcanic cup stands out on it (Nurković, 1982).

Javor is a mountain surrounded by the slopes of Čemernica in the northwest, Mučnja in the west, Golija in the east and Uvac in the southwest. The forested part of the mountain stretches between the rivers Uvac and Moravica, $16 \mathrm{~km}$ long. The highest peak is Vasilijin vrh $(1,519 \mathrm{~m})$. Between the heights of Javor, there is a slightly undulating surface, which is dissected by small hills and river valleys. On the south side of the mountain is Kalipolje, on a vast karst surface that stretches around the river Uvac. It is about $3 \mathrm{~km}$ long and about $2 \mathrm{~km}$ wide. It is inclined in the western direction, where there are surface and underground karst relief forms, created during the lake phase (Subotić, 2008).

Pobijenik is an elongated mountain of the Dinaric direction that stretches along the right side of Lim between Prijepolje and Priboj. It is built mainly of Jurassic sediments and to a lesser extent of Triassic limestones that often form steep rocky 
heights. Most of the mountain is covered with pastures, the higher parts are overgrown with beech forest and in the eastern part with conifers. An access is possible from several directions, from Priboj, Bistrica (on the river Lim), Prijepolje, Jabuka or the Poblaćnica valley (Drobnjaković, 2012).

Giljeva is a mountain located the south of Sjenica on the border with Montenegro. It belongs to the Stari Vlah-Raška mountains, and its highest peak Jelenak has a height of $1617 \mathrm{~m}$. It belongs to the cave plateau and is connected to Jadovnik and Ozren in the northwest and Bihor in the south. On the southwestern edge of the mountain there is the Đalovo gorge built of limestone (Lješević et al., 2004).

In addition to the mountains, we should mention other natural tourist values that make the tourist offer of southwestern Serbia richer and more diverse. Here we should definitely mention the Peshterska plateau, Kostam field, then numerous cave systems, among which the Ušac cave system, Stopić's cave, Tubić's cave and others stand out. The special attractiveness of this area are the gorges and canyon valleys, both with their curiosity and landscape values, and the richness of the animal world, where the valleys of Uvac, Lima and Crni Rzav stand out.

\section{Potentials of mountain tourism in southwestern Serbia}

The mountainous area of southwestern Serbia is characterized by a number of specifics that make it significantly different from other spatial units of the country by its horizontal and vertical disintegration, morphometric properties of relief, climatic, hydrological and biogeographical characteristics, as well as nature conservation. All these specifics enable the development of a number of economic activities, among which tourism occupies a significant place. In accordance with their tourist potentials, in the development of mountain areas so far, their recreational, health, sports-manifestation and cultural-manifestation form of tourist traffic has been favored and emphasized. However, only some mountains have significant natural and anthropogenic potentials that can be valorized and used for the development of winter and summer mountain tourism.

The procedure of valorization of the mountainous area of southwestern Serbia was preceded by a detailed inventory of all relevant elements that make up its overall tourism potential. These potentials are divided into two groups: natural and created (anthropogenic). By applying the method of a potential sharing, it is possible to compare a number of properties of different tourism resources: relief, climate, natural attractiveness of the area, market attractiveness of cultural goods (environment, importance, tourist value in the region, etc.), factors important for designing a tourism product, proximity to other cultural goods, etc.), cultural significance (aesthetic, historical, educational value, etc.). 
Natural factors and resources are objective factors that occur regardless of whether any tourist activity is initiated or not. They directly determine the tourist quality of the space, the degree of its attractiveness, as well as the possibility of its economic-geographical valorization from the aspect of tourism (Šušić, 2017). Natural factors that define and determine the overall attractiveness of the area and the direction of mountain tourism development are: tourist-geographical position, mountain size, the distribution of mountain mass and climatic characteristics. In doing so, all tourist-activated mountain areas (in varying degrees) were analyzed. On the other hand, there are completely non-established tourist areas, but they have different opportunities for tourism development.

The mountains of southwestern Serbia have different geographical, traffic and tourism positions. It is determined by traffic connections and distance from the important traffic and tourism routes, as well as the distance from the most important emitting areas in the country. The mountains of southwestern Serbia are among the medium-high mountains and are located in the hypsometric zone from $1,000 \mathrm{~m}$ to $1,500 \mathrm{~m}$ above sea level. They favor the development of various types of sports, recreation and recreational skiing. The relatively low altitude and the lack of snow do not allow the construction of larger ski centers. The values of the basic climatic elements of the mountains of southwestern Serbia, primarily Zlatibor, enable the development of summer and winter mountain tourism (to a much lesser extent). As with other mountains of medium height, the main limiting factor for the development of winter tourism is the thickness and duration of the snow cover.

The group of created potentials includes numerous infrastructure and suprastructure facilities in a mountain destination. The group of created potentials includes the degree of urbanization, the concentration of accommodation and catering capacities, facilities for recreation and entertainment, as well as other qualitative and quantitative properties of the superstructure.

Zlatibor is the most urbanized mountain center in the country with a significant degree of environmental devastation. The beginnings of the construction of tourist facilities are related to the period after the Second World War. In that period, it began an intensive construction of accommodation facilities on Zlatibor. In the last decade, with the establishment of the PE "Ski Resorts of Serbia", significant material funds have been invested in the construction of facilities required for winter sports. At the same time, the existing accommodation facilities were reconstructed and the new capacities of different quality and categories were built. The accommodation facilities on Zlatibor are intended for a heterogeneous tourist clientele. The biggest shortcoming on Zlatibor is the accommodation capacities of high categories.

According to the degree of urban construction, for example, Golija belongs to the undeveloped mountain areas of Serbia. The proclamation of this mountain as a biosphere reserve, as well as the lack of financial resources, slowed down the 
construction of the necessary facilities for the development of tourism. The construction of the tourist infrastructure in the area of Golija began in 1950. With the support of the Government of Serbia, the existing facilities were reconstructed, a ski trail was laid, a cable car was set up and a hotel was built (Nikolić, 2014).

The mountain centers of southwestern Serbia do not have a large concentration of accommodation and other facilities that can disrupt the landscape and the natural values of the mountains. The exceptions are the central parts of Zlatibor, where the concentration of tourist facilities is high, so they are more reminiscent of an urban settlement than a mountain tourist center. Ski slopes, cable cars and ski lifts are the most important sports and recreational facilities for the development of winter tourism. In the mountains, they are a decisive factor that crucially determines the length and quality of a stay in the destination with various contents. The most important ski slopes on the mountain Zlatibor are located on Tornik. In the area around Odvraćenica, there are five cable cars (ski lifts, anchors and saucers) arranged on seven trails. The slopes are good for Nordic and alpine skiing.

The specificity of mountain tourist centers in southwestern Serbia can be seen in relation to mountain tourist centers in the area, i.e. the neighboring countries, then we can consider the mutual competitiveness of mountain centers in Serbia or competitiveness in relation to the most developed mountain tourist destination in the country, Kopaonik. The competitiveness of southwestern Serbia as a tourist destination depends on the achieved level of quality of its tourism product in relation to the key success factors. Based on that, it can be stated that the competitiveness of tourism in a destination is higher, by the extent to which the level of quality of the tourism product is raised in relation to each individual success factor.

Southwestern Serbia is just at the beginning of creating its own tourism product and has the opportunity to use its current position, because it can learn from others, share their good and bad experiences, create a tourist product, act quickly on inherited infrastructure. Its real chances for entering the foreign market are: a global turnaround in tourism, products with the greatest business potential, a profile of new tourists and general market growth.

\section{Strategy for the conservation of mountain resources in southwestern Serbia}

The development of mountain tourism is conditioned by the development and preservation of mountain resources. Also, the need to preserve the mountain resources of a destination is one of the goals of long-term tourism development. However, it often happens that the development of tourism in one area, unknowingly or intentionally, leads to a deterioration in the quality of mountain resources, because especially in underdeveloped and developing countries, short- 
term profit from natural resources is in most cases the dominant goal of economic activities. Therefore, with the development of tourism in a certain area, it is necessary to monitor the effects of that development and possibly adopt certain corrective measures, i.e. to adapt the development of tourism to the requirements of all participants in the tourism market (tourists, local population and tourism industry). In that way, it would be possible to preserve mountain resources for future tourism and overall economic development, but also to avoid giving up the exploitation of resources, which would lead to a reduction in the economic performance of one country or another observed area.

In the context of natural resources to which mountain resources belong, it is understood that the use of natural resources in a sustainable way means ensuring their availability in the future and reducing the impact of their use on the environment. Therefore, the sustainable use and management of natural resources (renewable and non-renewable) requires the application of three key principles (National Strategy, 2012):

- The use of renewable resources must not exceed the rate of their renewal / regeneration

- The use of non-renewable resources must not exceed the rate at which the substitutes for those resources are developed

- The amount of substances released into the environment (pollution) must not exceed the capacity to transform the pollutants into harmless or less harmful to the living world.

Without going into too many numerous and often controversial theoretical considerations of the term tourist destination, i.e. what is necessary for a certain space to contain in order to be a tourist destination, the survival and development of these destinations must be harmonized with sustainable development. This means that each destination must adhere to a certain list of indicators of sustainable tourism development, which should show in which direction the development of tourism is going. It often happens that the economic effects of tourism development in a longer period of time are extremely favorable, i.e. the destination is profitable and well-positioned in the tourism market to experience a decline in economic performance at some point. This is the result of only one-sided, mostly economic observation of the tourist destination, and the neglect of observation of other aspects (sociological, ecological, political, cultural, etc.). In order to prevent such phenomena in the development of tourist destinations, it is necessary to harmonize the development of the destination with the list of relevant indicators of sustainable development, which aim to achieve the balance between the all identified goals of tourist destination development (Jovicic, Ilic, 2010).

The seasonal character of traffic is the most important economic indicator of sustainable tourism, which shows the share of the number of tourists in the period of the three most visited months, in relation to the total number of visitors during 
the year. The value of the observed indicator in the analyzed mountain destinations shows different values. Zlatar has the most critical value, where over $50 \%$ of tourist visits are concentrated in the three winter months, which is an unsustainable situation for the natural resources of this destination. This concentration of tourists in a short period of time has negative effects on the quality of the tourist experience, as well as on the endangerment of natural resources and the entire environment. It is possible to implement various measures to mitigate the seasonal character of the tourist traffic. This can be achieved by enriching the summer offer, introducing various contents, such as: schools in nature, hiking tours, mountain biking, picking herbs, collecting forest fruits, events, counseling, etc. On the other hand, relatively developed mountain destinations, Zlatibor and Golija, achieve sustainable values of the analyzed indicator (below $40 \%$ ). This especially refers to Zlatibor, which has the most uniform visit of tourists by months, so that in the three most visited months it realizes $30 \%$ of the total visit during the year. This is an acceptable solution from the point of view of sustainable tourism and sustainable use of natural resources, because the pressure on natural resources is relatively evenly shown and shows that developed forms of tourism that do not depend crucially on climatic factors. Therefore, according to the seasonal character of traffic, the mountain destination Zlatibor has the best indicators from the point of view of sustainable tourism.

The ratio of overnight stays and accommodation capacities is an important economic indicator of sustainable tourism in mountain tourist destinations. The ratio of the number of tourist nights and accommodation capacities is an indicator of the economic turnover that is realized in the destination. It is estimated that the ratio of the mentioned factors must not be below 120 nights per bed per year; if it ranges between 120 and 150 nights per bed, the capacity utilization is acceptable, but not at the optimal level, while sustainable capacity utilization is achieved when the value of this indicator is 150 or more nights per bed (Jovicic, Ilic, 2010). A sustainable use of capacity within southwestern Serbia is achieved on Zlatibor and Zlatar, where this indicator is over 150 nights per bed.

The coefficient of local tourist increase is the most important economic indicator of sustainable tourism development in one area, which aims to indicate all direct and indirect impacts that tourist consumption and employment have on the local economy, because it is known that primary consumption induces the so-called secondary consumption, which favorably affects the economy of the tourist place as a whole and the region to which it belongs. Regarding the value of this indicator, there are no precise, quantitative data on its value in the observed area, so it is possible to give only a qualitative assessment. Considering the development of other industries in the analyzed destinations, it can be concluded that tourism has not significantly contributed to the development of other industries, because the products of the local area (except for a number of agricultural products) are quite modestly included in the tourist offer. The economic underdevelopment of other 
economic branches also contributes to that, but also the lack of human resources, which could be included in the development and placement of products on the tourist market. According to available data, the destinations of Zlatibor, Golija and Zlatar made the best use of tourism as a branch that led to the growth of the local economy, while the other analyzed mountain destinations did not use the development of tourism to increase.

Repeated visits are an indicator of tourist satisfaction with a particular destination. Most destinations do not keep detailed statistics of repeated tourist visits, so there is no precise data for the value of this parameter. This indicator is very important for each destination, because repeated visits represent the fact that the tourist destination is well-positioned in the tourist market and that the tourism product it offers is acceptable to the existing tourists. Bearing in mind that modern tourists strive to get to know new, unexplored and unknown destinations, it is considered that the period of revisiting one destination within 5 years is quite acceptable for each destination. Due to the specific product that mountain destinations offer to tourists, as well as due to relatively underdeveloped competition in the domestic and neighboring countries, the percentage of repeated visits in the destination of Zlatibor is higher than the recommended 50\%, while Golija and Zlatar and other mountains are below the sustainable limits. (Dragović, 2001).

The relationship between the accommodation capacity and the number of local population can be viewed from two aspects. First, from the aspect of cultural impact in terms of the architectural appearance of the tourist area or place, and secondly, from the aspect of the requirement to provide the necessary infrastructure, which burdens the budget of local communities. So, if the number of beds is oversized, then the impression of overcrowding of the tourist place is obtained, which adversely affects the quality of the tourist experience. Zlatibor and Zlatar have an unsustainable value of this indicator, while other analyzed destinations have a sustainable value of this indicator, because the number of accommodation units is significantly lower compared to the previous two destinations. This indicator, if viewed in isolation, is not precise enough because there are examples where tourist destinations have a large number of beds, a small number of locals, but also a small tourist turnover, so that tourist destination cannot be claimed to be overloaded.

Tourism intensity is another indicator from the group of cultural indicators, which is somewhat more precise and complements the previous one. It represents the ratio between the number of tourist nights (in thousands) and the number of local population (in hundreds). The value of this indicator in the observed destinations shows the unsustainable values. However, when applying this indicator, its interpretation should not be approached in the same way for each tourist place or region to which they are applied, but certain specifics of a certain place or region must be taken into account, which then changes the relative importance of this relationship. 
The share of tourism in the local net product shows the contribution of tourism to the creation of the social product of the observed area. Due to the lack of precise quantitative indicators, it is possible to give a qualitative assessment of this indicator.

The percentage of tourists who do not come through a tour operator is an indicator which aims to highlight the negative social effects that may occur if tourists come in an organized manner, i.e. through a tour operator. Namely, if tourists come in an organized manner, in larger groups, according to the interpretation of the creators of this indicator, they can cause a great negative impact on the local population in terms of social pressure on their lifestyle and the like. (Jovicic, Ivanovic, 2006).

The percentage of land on which the construction is allowed (but not realized) shows the degree of missed chances for tourism development, i.e. which part of the land intended for the construction of accommodation and other capacities has not been used for those purposes. The more developed mountain destinations of Serbia (Zlatibor, Zlatar and Golija) have used the largest part of the land intended for the tourist construction, while other mountains have a relatively large part of the unused land planned for the construction of tourist infrastructure.

The land use and the occupation is an indicator that shows how much of the land has been used to build accommodation and other tourist facilities. There is no quantitative assessment for this indicator. Analyzing the degree of capacity building of the observed mountain destinations, it can be concluded that the destinations Zlatibor and Golija are overbuilt, in terms of the observed indicator, that Zlatar has an acceptable value of this indicator, while other mountains are insufficiently built tourist destinations.

The percentage of tourists who do not come by private cars is an indicator that provides significant data on the impact of tourism on the environment, because the use of their own cars leads to an increased environmental pollution. Unfortunately, the destination management does not keep records of the guests' means of transport. As a rule, if tourists come en masse through tour operators, then the percentage of those who use their own vehicle is smaller and vice versa. In the area of Zlatibor, Zlatar and Golija, due to the fact that they have a relatively good connection with bus lines, they have a slightly better value of the observed indicator. Zlatibor has the best value of the analyzed indicator of sustainability, which fully corresponds to the previously stated position that the most numerous tourists are organized groups of students and preschool children.

\section{Conclusion}

In order to initiate sustainable tourism development in mountainous areas, as well as to improve the potential of these tourist destinations, it is necessary to review the 
current development processes in the mountain areas, the international conventions and standards of mountain development, the successful examples of development projects and apply the domestic and foreign experiences. The experiences of the development of mountain areas in other countries and other parts of the Republic of Serbia point to the conclusion that there is no single model of development and arrangement of mountain areas, but that it is necessary to know the specifics of each mountain individually.

The development of mountain tourism in southwestern Serbia should be based on the multifunctionality of the mountain activities and the gradual integration of the local population into the development of tourism. The role of agriculture as a local source of food, employment and income is important, but insufficient for the development of the area and the retention of the population. Also, the orientation only to tourism increases the dependence on unpredictable external markets and climatic conditions (Milijić et al., 2009)

If development is based on tourism, agriculture and other complementary activities, the risk is diversified and the local economy has more chances. A diversified economy based on natural resources is a means of retaining and returning people to mountainous areas and would enable a more balanced regional development of this part of Serbia. By valorizing the potential of the mountains of southwestern Serbia, it can be concluded that they cannot reach the level of development of individual mountains of Austria, France or Switzerland, but can approach the tourist offer of the mountain centers of Bulgaria and Romania. The main goal of spatial development of the mountainous areas of southwestern Serbia is the protection and presentation of the mountainous areas as an exceptional natural resource of the state, according to high standards and norms established by European and domestic documents, with the possibility of sustainable development that will not disturb the balance of natural systems, population, as well as creating conditions for vacation and recreation of the urban population, in accordance with the capacities of nature.

\section{References}

Debarbieux B., Varacca M., Rudaz G. (2014). Challenges and opportunities for tourism development in mountain regions. Tourism in Mountain Regions. Department of Geography and Environment. University of Geneva

Dinić J. (1976). Fizičko-geografske odlike područja Zlatara. Republički zavod za zaštitu prirode. Beograd

Dragović R. (2001). Ekološko-turističke odlike i perspektive Zlatara. Zavod za zaštitu prirode Srbije, Zaštita prirode 53/1. Beograd

Drobnjaković J. (2012). Prijepolje: faktor regionalne integracije Jugozapadne Srbije. Geografski institut „Jovan Cvijić“ SANU. Beograd

Jovičić D., Ivanović V. (2006). Turizam i prostor. Ton PLUS. Beograd 
Jovičić D., Ilić T. (2010). Indikatori održivog turizma. Glasnik srpskog geografskog društva, tom 90, br. 1, Beograd

Lješević M., Obradović D., Milanović M. (2004). Sjenički kraj-antropogena proučavanja. Zaštićena prirodna dobra kao faktor razvoja. Geografski fakultet Univerziteta $\mathrm{u}$ Beogradu. Beograd

Marković J., Pavlović M. (1995). Geografske regije Jugoslavije (Srbija i Crna Gora). Savremena administracija. Beograd

Milijić S., Banićević D., Krunić N. (2009). Strategic evaluation of economic feasibility of tourist region development. SPATIUM br. 19. Beograd

Mountains of the world: Tourism and sustainable mountain development. (1999). Institute of Geography. University of Berne

Nacionalna strategija održivog korišćenja prirodnih resursa i dobara (2012). Službeni glasnik RS br. 33/2012-3

Nikolić, S., Jovičić, Ž. (2004). Strateško-programske osnove razvoja Golije. Udruženje turizmologa Beograda. Beograd

Nikolić, S. (2014). Golija ekološko turistička studija sa programskom osnovom. Srpsko geografsko društvo. Beograd

Nurković, S. (1982). Prilog poznavanju regionalno-geografske izdvojenosti $i$ interne strukture Sandžačko-starovlaškog. Geografski glasnik, br. 44. Zagreb

Romelić, J. (2008). Turistička geografija Srbije. Departman za geografiju, turizam i hotelijerstvo, PMF u Novom Sadu. Novi Sad

Ršumović R., Milojević M., Lazarević M. (1991). Zlatibor - geografska studija. SANU. Odeljenje društvenih nauka. knj. 100. Beograd

Spasojević, M., Šušić, V. (2016). Razvoj turizma u planinskim prostorima. Antikrizne politike i postkrizni procesi: izazovi ekonomske nauke. Zbornik radova. Ekonomski fakultet. Niš

Subotić, V. (2008). Planina Javor u istoriji Srba. Humanitarna organizacija „Stara Raška”. Beograd

Šušić V. (2017). Turistička geografija. Ekonomski fakultet Univerziteta u Nišu. Niš

\section{POTENCIJALI RAZVOJA PLANINSKOG TURIZMA JUGOZAPADNE SRBIJE}

Rezime: Planinska područja Republike Srbije sa svojim okruženjem i objektima, javljaju se kao značajni delovi turističkih regija sa potencijalom za razvoj komplementarnih aktivnosti i celogodišnjeg turizma. Mogućnosti razvoja planinskog turizma zavise od veličine planinskog područja, režima zaštite prirode, opremljenosti infrastrukturom, stvaranja uslova za odmor i rekreaciju i uključivanja lokalnog stanovništva $u$ proces razvoja $i$ zaštite. Prostor jugozapadne Srbije ima kvalitetne i raznovrsne potencijale za razvoj planinskog turizma, od kojih je samo deo aktiviran. U radu se analiziraju potencijali i brojne razvojne mogućnosti planinskog turizma, sa posebnim akcentom na planine koje su do sada ostajale na marginama turističkog privređivanja.

Ključne reči: planina, planinski turizam, jugozapadna Srbija, Zlatibor, turistički potencijal 


\section{Authors' biographies}

Ljiljana Lešević, is currently $\mathrm{PhD}$ candidate at the Faculty of Economics in Niš. In the period from 2015 to 2018, she worked as a director in the public institution Tourist Organization of the City of Novi Pazar, and since 2018 as a Coordinator in the information center at the Tourist Organization of the City of Novi Pazar. She participated in many educational seminars and obtained certificates in various fields. In 2018, she was appointed by the Mayor of Novi Pazar as the team leader for the development of the Strategy for Sustainable Tourism Development of the City of Novi Pazar for a period of ten years. From 2015 to 2019, she published several scientific papers in the field of tourism marketing and management, demography and economic development at scientific conferences and journals in the country and abroad.

Dejan Ž. Đorđević is Full Professor at Faculty of Economics, University of Niš., where he teaches undergraduate courses in Economic Geography, Tourism Geography and Regional Geography. He has authored numerous scientific and research articles in various kinds of publication and also published scientific and professional papers in domestic and international journals in the fields of Economic and Tourism Geography.

Vukašin Šušić is a Full Professor at the Faculty of Economics in Niš. He teaches at the basic academic studies, graduate academic master studies and $\mathrm{PhD}$ studies, the subjects from scientific area of economic geography. From 2003 to 2014 he was a honorary associate at the Department of Geography of the Faculty of Natural Science and Matematics in Niš for industrial and agrarian geography subjects. He published over 70 works and participated in many scentific meetings. $\mathrm{He}$ is the author of the Tourism Geography coursebook and a coauthor of the Economic Geography - Serbian and Montenegro and Geography of the World course books. He is a member of the Serbian Geographical Society. 